\title{
Bacillus cecembensis sp. nov., isolated from the Pindari glacier of the Indian Himalayas
}

\author{
Correspondence \\ S Shivaji \\ shivas@ccmb.res.in
}

\author{
G. S. N. Reddy, Anarasi Uttam and S. Shivaji \\ Centre for Cellular and Molecular Biology, Uppal Road, Hyderabad 500 007, India
}

The genus Bacillus was created by Cohn (1872), with Bacillus subtilis as the type species. Members of the genus Bacillus are distinguished from other endospore-forming bacteria on the basis of being strict or facultative aerobes, rod-shaped, (usually) catalase-positive and they contain meso-diaminopimelic acid (meso-Dap) in the peptidoglycan, MK-7 as the major menaquinone and iso- $\mathrm{C}_{15: 0}$ and anteiso- $\mathrm{C}_{15: 0}$ as major fatty acids and have DNA $\mathrm{G}+\mathrm{C}$ contents of 32-69 mol\%. Interestingly, Bacillus is the only genus that contains organisms with L-lysine (Lee et al., 2006; Rheims et al., 1999) or ornithine (Spanka \& Fritze, 1993; Abd El-Rahman et al., 2002) as the diamino acid in the peptidoglycan, in addition to meso-Dap, which is present in the majority of species. At the time of writing, 212 species and subspecies are recognized in the genus Bacillus (http://www.dsmz.de/microorganisms). The ubiquitous distribution of Bacillus species in nature is due to the resistance of their endospores to chemical and physical agents. Species of Bacillus have been shown to be resistant to radiation (Shivaji et al., 2006; Venkateswaran et al.,

Abbreviation: Dap, diaminopimelic acid.

The GenBank/EMBL/DDBJ accession number for the $16 \mathrm{~S}$ rRNA gene sequence of strain $P N 5^{\top}$ is $A M 773821$.

A transmission electron micrograph of a cell of strain $P N 5^{\top}$ and $16 \mathrm{~S}$ rRNA gene sequence-based trees generated by UPGMA, minimum evolution and DNAPARS are available as supplementary material with the online version of this paper.
2003), extremely low temperatures (Brambilla et al., 2001; Logan et al., 2000; Forsyth \& Logan, 2000; Rüger et al., 2000; Nelson \& Parkinson, 1978; Abd El-Rahman et al., 2002; Lechner et al., 1998), high temperatures (Baker et al., 2001; Caccamo et al., 2000; Combet-Blanc et al., 1995), salinity (Lim et al., 2006; Lee et al., 2006; Gugliandolo et al., 2003), alkalinity (Nogi et al., 2005; Vargas et al., 2005; Yumoto et al., 1998), acidity (Albert et al., 2005) and high pressure (Bae et al., 2005). Although Bacillus species have been isolated from a wide range of habitats, only one Bacillus species with a validly published name, Bacillus lehensis (Ghosh et al., 2007), has been isolated from the Himalayan region. In the present study, a unique psychrotolerant Bacillus strain $\left(\mathrm{PN}^{\mathrm{T}}{ }^{\mathrm{T}}\right.$ ) containing L-lysine as the diamino acid in the peptidoglycan was isolated from a soil sample of the Pindari glacier of the Indian Himalayas; based on polyphasic taxonomic characterization, it is identified as representing a novel species.

Strain $\mathrm{PN} 5^{\mathrm{T}}$ was isolated from a soil sample collected close to the Pindari glacier at an altitude of approximately $3500 \mathrm{~m}$. Approximately $200 \mathrm{mg}$ of the soil sample was suspended in $0.9 \%$ saline, subjected to shaking for $1 \mathrm{~h}$ and allowed to settle and $100 \mu \mathrm{l}$ was plated on nutrient agar plates $[0.3 \%$ beef extract, $0.5 \%$ peptone, $0.8 \% \mathrm{NaCl}$ and $1.5 \%$ agar (all w/v)]. The viable bacterial cell count was approximately $2.1 \times 10^{5}$ c.f.u. and, based on colony morphology, 40 different morphotypes were observed. In the present study, one of the morphotypes in which the 
colony was opaque and white was picked up, purified, maintained on nutrient agar plates and studied in detail. Morphology was studied using light microscopy and transmission electron microscopy (Reddy et al., 2006). Motility was assessed on $0.4 \%$ nutrient agar plates and also by light microscopy. Spore staining was done using Schaeffer \& Fulton's spore-staining kit (K006-1KT; HiMedia) according to the manufacturer's protocol. Growth and biochemical characteristics, carbon assimilation and sensitivity of cultures to different antibiotics were determined by previously described methods (Lányí, 1987; Reddy et al., 2006; Smibert \& Krieg, 1994). Biochemical characteristics were also checked with the Hi25 Enterobacteriaceae identification kit (KB003) and HiCarbohydrate kit parts A, B and C (KB009) (both from HiMedia) according to the manufacturer's protocol.

For quantitative analysis of whole-cell fatty acids, cells of PN5 $5^{\mathrm{T}}$ were grown on tryptic soy agar (TSA) at $28{ }^{\circ} \mathrm{C}$ for 2 days and extracted and analysed by using the Sherlock Microbial Identification System (MIDI) according to the protocol described by Agilent Technologies. Lipids were extracted and analysed by one-dimensional TLC using a pre-coated silica gel plate as described previously (Suresh et al., 2004). Peptidoglycan was prepared and analysed according to the method of Komagata \& Suzuki (1987). Isoprenoid quinones were extracted according to the method of Collins et al. (1977) and separated by HPLC using an isocratic solvent system of methanol/isopropyl ether (3:1) (Tamaoka et al., 1983; Tamaoka, 1986).

DNA from strain $\mathrm{PN} 5^{\mathrm{T}}$ was isolated using the Microbial DNA isolation kit (Mo Bio Laboratories). The 16S rRNA gene was amplified by PCR and sequenced as described previously (Reddy et al., 2000). The almost full-length sequence containing 1478 nucleotides (positions 27-1491, according to the Escherichia coli 16S rRNA gene sequence) was aligned with closely related sequences belonging to the genera Bacillus, Caryophanon, Kurthia, Sporosarcina, Filibacter and Planococcus using CLUSTAL W (Thompson et al., 1994). Pairwise evolutionary distances were computed using the DNADIST program with Kimura's two-parameter model (Kimura, 1980). Phylogenetic trees were constructed using four different tree-making algorithms (neighbour-joining, maximum evolution, UPGMA and DNAPARS) using the MEGA 3 software package (Kumar et al., 2001). Bootstrap analysis was performed with 1000 replicate datasets in order to assess stability among the clades recovered in the phylogenetic tree. DNA-DNA hybridization was performed by the membrane filter method as described previously (Pandey et al. 2002; Reddy et al., 2002). Bacillus silvestris DSM $12223^{\mathrm{T}}$ was used as a reference strain for comparing the peptidoglycan, lipids and menaquinones and for DNA-DNA hybridization.

Isolate $\mathrm{PN}^{\mathrm{T}}$ is a Gram-positive, motile, rod-shaped bacterium with peritrichous flagella and possesses terminally located spores. The rods are approximately $3.5 \mu \mathrm{m}$ long and $1.25 \mu \mathrm{m}$ wide (Supplementary Fig. S1, available in IJSEM Online). Cells are catalase-positive and oxidase- negative and contain lysine, glutamic acid and alanine in the peptidoglycan (peptidoglycan type $\mathrm{A} 4 \alpha$ ). The cells are characterized by the presence of iso- $\mathrm{C}_{15: 0}$ and iso- $\mathrm{C}_{16: 1}$ as the predominant fatty acids and MK-7 as the lone isoprenoid quinone. Based on the above characteristics, strain $\mathrm{PN}^{\mathrm{T}}$ was assigned to the genus Bacillus. The placement of the strain within the genus Bacillus was further supported by phylogenetic analysis based on the $16 \mathrm{~S}$ rRNA gene sequence, wherein it clustered with the type strain of Bacillus silvestris (Rheims et al., 1999) with bootstrap resampling values of $83,94,87$ and $54 \%$, respectively, with the neighbour-joining (Fig. 1), UPGMA, maximum evolution and DNAPARS methods (Supplementary Fig. S2). In addition, BLAST analysis based on the 16S rRNA gene sequence further supported its close relationship with Bacillus silvestris by exhibiting a sequence similarity of $97.2 \%$ to the type strain (a difference of 39 nucleotides with 2 gaps out of 1478 nucleotides). The other closely related type strains that shared more than $95 \% 16 \mathrm{~S}$ rRNA gene sequence similarity with $\mathrm{PN}^{\mathrm{T}}$ are those of Bacillus sphaericus (96.8\%), Bacillus fusiformis (95.6\%), Caryophanon tenue (95.9\%) and Caryophanon latum $(95.8 \%)$. The above similarity suggests that strain $\mathrm{PN}^{\mathrm{T}}$ may represent a distinct species. However, DNA-DNA hybridization between strain $\mathrm{PN5}^{\mathrm{T}}$ and B. silvestris DSM $12223^{\mathrm{T}}$ resulted in a relatedness of only $15 \%$, clearly suggesting that strain $\mathrm{PN}^{\mathrm{T}}$ represents a novel species (Wayne et al., 1987). In addition to these important characteristics, $\mathrm{PN}^{\mathrm{T}}$ exhibited number of differences from B. silvestris, the phylogenetically closest relative, with respect to growth characteristics, biochemical parameters and lipid and fatty acid composition (Tables 1 and 2).

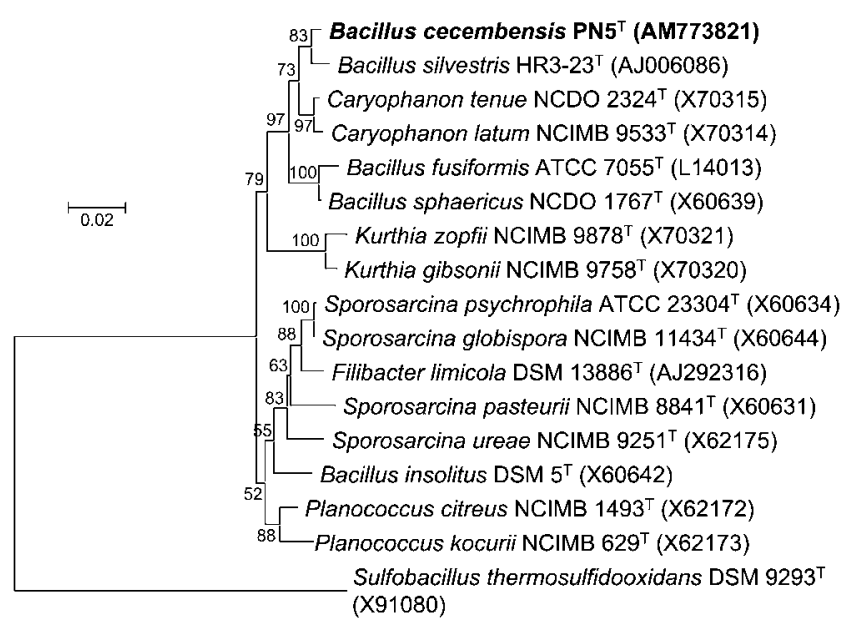

Fig. 1. Neighbour-joining tree, based on 16S rRNA gene sequences (1478 bases), showing the phylogenetic relationships between Bacillus cecembensis sp. nov. $\mathrm{PN5}^{\top}$ and related taxa. Bootstrap values (expressed as percentages of 1000 replications) greater than $50 \%$ are given at nodes. Sulfobacillus thermosulfidooxidans DSM $9293^{\mathrm{T}}$ was used as the outgroup. Bar, 2 substitutions per 100 nucleotides. 
Table 1. Characteristics that differentiate strain $P N 5^{\top}$ from $B$. silvestris DSM $12223^{\top}$

Data for B. silvestris DSM $12223^{\mathrm{T}}$ were taken from Rheims et al. (1999).

\begin{tabular}{|lcc|}
\hline Characteristic & PN5 $^{\mathbf{T}}$ & $\begin{array}{c}\text { B. silvestris } \\
\text { DSM 12223 }\end{array}$ \\
\hline $\begin{array}{l}\text { Growth temperature }\left({ }^{\circ} \mathrm{C}\right) \\
\quad \text { Range }\end{array}$ & $4-30$ & $10-40$ \\
$\quad$ Optimum & 25 & $20-30$ \\
Tolerance to NaCl (\%) & $0-3$ & $0-5$ \\
pH range for growth & $6-8$ & $6-7$ \\
Lipase & + & - \\
Utilization of: & - & + \\
$\quad$ D-Ribose, glycerol & + & - \\
Trehalose, glucosamine, & & \\
$\quad$ citrate & PG, DPG, & PG, DPG, PE, \\
Lipids & (PC) & (PS), (PL) \\
& & \\
\end{tabular}

${ }^{\star}$ DPG, Diphosphatidylglycerol; PC, phosphatidylcholine; PE, phosphatidylethanolamine; PG, phosphatidylglycerol; PS, phosphatidylserine; PL, unknown phospholipid. Minor components are listed in parentheses.

Based on these differences, it is proposed to assign $\mathrm{PN}^{\mathrm{T}}$ to a novel species of the genus Bacillus, and the name suggested is Bacillus cecembensis sp. nov.

It is interesting to note that strain $\mathrm{PN}^{\mathrm{T}}$ and B. silvestris cluster with the clade representing species of the genus Caryophanon, implying that they are phylogenetically closely related to the genus Caryophanon (Fig. 1). However, B. cecembensis sp. nov. and B. silvestris can be differentiated from the species of Caryophanon since they contain MK-7 as the isoprenoid quinone, whereas Caryophanon species contain MK-6. Thus, the affiliation of B. cecembensis and B. silvestris to the genus Bacillus is unambiguous.

B. cecembensis is one of the very few psychrotolerant species of the genus Bacillus. Only six species have so far been reported. Five of these species exhibit growth temperature ranges of $0-30{ }^{\circ} \mathrm{C}$ [Bacillus psychrotolerans and B. psychrodurans (Abd El-Rahman et al., 2002), B. psychrosaccharolyticus (Priest et al., 1988), B. insolitus (Larkin \& Stokes, 1967) and B. marinus (Rüger et al., 2000)], whereas Bacillus weihenstephanensis is able to grow at $4-43{ }^{\circ} \mathrm{C}$ (Lechner et al., 1998). Rüger et al. (2000) and Abd El-Rahman et al. (2002) compared the morphological and physiological characteristics of psychrotolerant Bacillus species, but Bacillus globisporus and Bacillus psychrophilus have since been transferred to the genus Sporosarcina (Yoon et al., 2001). With the addition of B. cecembensis sp. nov., an attempt was made to re-evaluate the morphological, biochemical, chemotaxonomic and phylogenetic differences between psychrotolerant strains of Bacillus.
Table 2. Fatty acid methyl ester profiles of strain $\mathrm{PN}^{\top}$ and $B$. silvestris DSM $12223^{\top}$

Data for B. silvestris DSM $12223^{\mathrm{T}}$ were taken from Rheims et al. (1999) (only components present at $0.9 \%$ or above were reported). Values are percentages of total fatty acids. - , Not detected $\left(\mathrm{PN}^{\mathrm{T}}\right)$ or not reported (B. silvestris DSM $12223^{\mathrm{T}}$ ).

\begin{tabular}{|c|c|c|}
\hline Fatty acid & PN5 $5^{T}$ & B. silvestris DSM $12223^{\mathrm{T}}$ \\
\hline $\mathrm{C}_{12: 0}$ & 0.1 & - \\
\hline iso- $\mathrm{C}_{13: 0}$ & 0.6 & - \\
\hline $\mathrm{C}_{13: 0}$ & 0.1 & - \\
\hline $\mathrm{C}_{14: 0}$ & 1.1 & - \\
\hline iso- $\mathrm{C}_{14: 0}$ & 8.8 & 2.9 \\
\hline iso- $\mathrm{C}_{15: 0}$ & 36.5 & 44.2 \\
\hline anteiso- $\mathrm{C}_{15: 0}$ & 8.9 & 5.6 \\
\hline $\mathrm{C}_{16: 1} \omega 7 c$ alcohol & 14.5 & - \\
\hline iso- $\mathrm{C}_{16: 0}$ & 10.6 & 6.2 \\
\hline $\mathrm{C}_{16: 1} \omega 11 c$ & 5.4 & 3.1 \\
\hline iso- $\mathrm{C}_{16: 1}$ & - & 18.7 \\
\hline $\mathrm{C}_{16: 1} \omega 5 c$ & 0.1 & - \\
\hline $\mathrm{C}_{16: 0}$ & 2.6 & - \\
\hline $\mathrm{C}_{16: 0} 3-\mathrm{OH}$ & 0.1 & - \\
\hline iso- $\mathrm{C}_{17: 1} \omega 10 c$ & 1.8 & 7.8 \\
\hline anteiso- $\mathrm{C}_{17: 1} \mathrm{~A}$ & 0.1 & 2.8 \\
\hline iso- $\mathrm{C}_{17: 0}$ & 1.9 & 5.1 \\
\hline anteiso- $\mathrm{C}_{17: 0}$ & 2.0 & 3.0 \\
\hline $\mathrm{C}_{17: 1} \omega 9 c$ & 0.8 & - \\
\hline $\mathrm{C}_{17: 1} \omega 5 c$ & 0.3 & - \\
\hline $\mathrm{C}_{17: 0}$ & 0.2 & 1.0 \\
\hline iso- $\mathrm{C}_{18: 0}$ & 0.2 & - \\
\hline $\mathrm{C}_{18: 1} \omega 9 c$ & 0.4 & - \\
\hline $\mathrm{C}_{18: 1} \omega 5 c$ & 0.1 & - \\
\hline $\mathrm{C}_{18: 0}$ & 0.1 & - \\
\hline $\mathrm{C}_{18: 1} 2-\mathrm{OH}$ & 0.1 & - \\
\hline $\mathrm{C}_{20: 4} \omega 6,9,12,15 c$ & 0.1 & - \\
\hline \multicolumn{3}{|l|}{ Summed features ${ }^{*}$} \\
\hline 3 & 0.3 & - \\
\hline 4 & 1.1 & - \\
\hline 5 & 0.5 & - \\
\hline 8 & 0.1 & - \\
\hline
\end{tabular}

${ }^{*}$ Summed feature 3 contains $\mathrm{C}_{16: 1} \omega 7 c$ and/or $\mathrm{C}_{16: 1} \omega 6 c$; summed feature 4 contains iso- $\mathrm{C}_{17: 1} \mathrm{I}$ and/or anteiso- $\mathrm{C}_{17: 1} \mathrm{~B}$; summed feature 5 contains ante- $\mathrm{C}_{18: 0}$ and/or $\mathrm{C}_{18: 2} \omega 6,9 c$; summed feature 8 contains $\mathrm{C}_{18: 1} \omega 7 c$ and/or $\mathrm{C}_{18: 1} \omega 6 c$.

Comparative analyses indicate that all the species are distinct, as they all differ with respect to biochemical properties (Table 3). Interestingly, most of the psychrotolerant strains cluster together (supported by a significant bootstrap value of $96 \%$ ) with the exception of $B$. psychrosaccharolyticus and B. marinus (very low bootstrap values, of less than $50 \%$ ) (Fig. 2), so it is tempting to suggest that the 16S rRNA gene sequence contains adaptive signatures for psychrotolerance. B. cecembensis $\mathrm{PN}^{\mathrm{T}}$ also is unique among psychrotolerant strains in possessing urease activity and L-Lys-D-Glu in its cell wall (Table 3); the other 
Table 3. Characteristics that distinguish the psychrotolerant species of the genus Bacillus

Taxa: 1, B. cecembensis sp. nov. PN5 ${ }^{\mathrm{T}}$ (data from the present study); 2, B. psychrotolerans (Abd El-Rahman et al., 2002); 3, B. psychrodurans (Abd ElRahman et al., 2002); 4, B. psychrosaccharolyticus (Larkin \& Stokes, 1967; Priest et al., 1988); 5, B. marinus (Claus \& Berkeley, 1986; Rüger et al., 2000); 6, B. insolitus (Larkin \& Stokes, 1967; Claus \& Berkeley, 1986); 7, B. weihenstephanensis (Lechner et al., 1998). +, Positive; -, negative; v, variable; NA, data not available.

\begin{tabular}{|c|c|c|c|c|c|c|c|}
\hline Property & 1 & 2 & 3 & 4 & 5 & 6 & 7 \\
\hline Spore shape & Round & Round & Round & Ellipsoid & $\begin{array}{r}\text { Round or } \\
\text { ellipsoid }\end{array}$ & $\begin{array}{l}\text { Round or } \\
\text { cylindrical }\end{array}$ & Not round \\
\hline \multicolumn{8}{|l|}{ Growth temperature $\left({ }^{\circ} \mathrm{C}\right)$} \\
\hline Minimum & 4 & -2 & -2 & $0-2$ & $<1-4$ & $<0$ & 4 \\
\hline Maximum & 30 & 30 & 30 & 30 & 30 & 25 & 43 \\
\hline $\begin{array}{l}\text { Maximum } \mathrm{NaCl} \\
\text { concentration }(\%)\end{array}$ & 3 & 3 & 5 & 3 & 2.4 & 2 & 10 \\
\hline Anaerobic growth & - & - & - & + & - & - & - \\
\hline Oxidase & - & + & + & - & + & + & - \\
\hline \multicolumn{8}{|l|}{ Hydrolysis of: } \\
\hline Starch & - & + & + & - & - & - & + \\
\hline Nitrate reduction & + & - & + & + & $\mathrm{V}$ & - & + \\
\hline Cell-wall type & L-Lys-D-Glu & L-Orn-D-Glu & L-Orn-D-Glu & meso-Dap & L-Lys (direct) & L-Orn-D-Glu & meso-Dap \\
\hline rRNA group & 2 & 2 & 2 & 1 & 2 & 2 & 2 \\
\hline
\end{tabular}

psychrotolerant strains contained either L-Orn-D-Glu or meso-Dap or L-Lys (direct) peptidoglycan types. The phylogenetic analyses also indicated that strain $\mathrm{PN} 5^{\mathrm{T}}$ is different from $B$. lehensis from the Indian Himalayas (Ghosh et al., 2007) and Bacillus fumarioli from Antarctica (Logan et al., 2000), raising the possibility that these species are epidemic in their distribution. B. cecembensis sp. nov. $\mathrm{PN} 5^{\mathrm{T}}$ is an interesting organism as it can grow on very few carbon sources (only three of almost 40 tested) and is sensitive to all but two of the tested antibiotics.

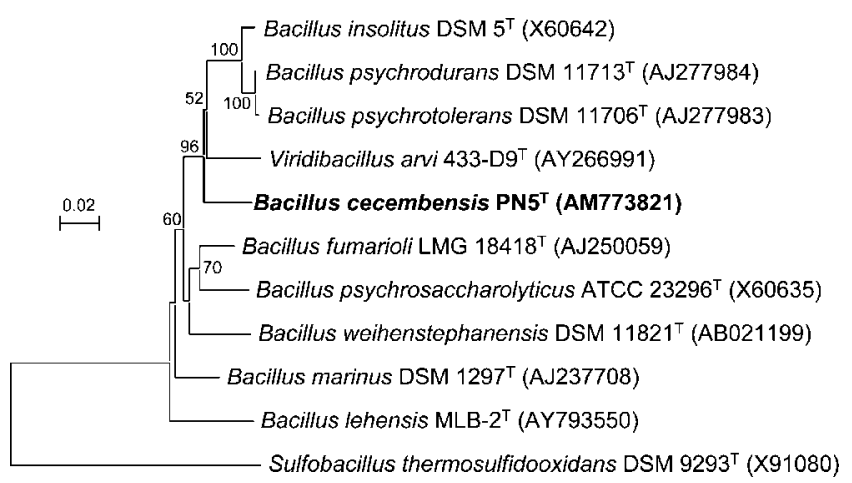

Fig. 2. Neighbour-joining tree, based on $16 \mathrm{~S}$ rRNA gene sequences (1478 bases), showing the phylogenetic relationships between psychrotolerant species of Bacillus. See Fig. 1 for further details.

\section{Description of Bacillus cecembensis sp. nov.}

Bacillus cecembensis (ce.cem.ben'sis. N.L. masc. adj. cecembensis arbitrary name derived from the acronym CCMB for the Centre for Cellular and Molecular Biology, where the type strain was characterized).

Colonies are irregular, opaque and flat and cells are Grampositive, motile, rod-shaped $(3.5 \mu \mathrm{m}$ long and $1.25 \mu \mathrm{m}$ wide), peritrichously flagellated and possess round, terminally located spores. Grows at $4-30{ }^{\circ} \mathrm{C}$ with optimum growth at $25^{\circ} \mathrm{C}$. Positive for catalase, lipase, phosphatase, urease, ornithine decarboxylase, nitrate reduction and $\beta$ galactosidase (nitrate reduction and $\beta$-galactosidase negative on HiMedia kits) but negative for oxidase, lysine decarboxylase, phenylalanine deamination, indole production, methyl red and Voges-Proskauer tests and hydrolysis of aesculin, gelatin and starch. Utilizes trehalose, glucosamine and citrate but not D-glucose, erythritol, D- or Larabinose, D- or L-xylose, adonitol, methyl $\alpha$-D-glucoside, methyl $\alpha$-D-mannoside, galactose, mannose, D-mannitol, D-fructose, L-sorbose, D-rhamnose, dulcitol, myo-inositol, sorbitol, $\mathrm{N}$-acetylglucosamine, aesculin, salicin, cellobiose, maltose, lactose, melibiose, sucrose, inulin, melezitose, raffinose, xylitol, D-glucuronic acid, sucrose, dextran, sodium gluconate, malonate, L-isoleucine, L-glutamine, Lalanine, L-threonine, L-phenylalanine, L-proline, L-lysine, L-serine, L-tyrosine, L-histidine, L-leucine or L-aspartic acid. Cells are resistant to ( $\mu \mathrm{g}$ per disc unless indicated) nalidixic acid (30) and streptomycin (10) but sensitive to 
amikacin (30), ampicillin (10), bacitracin (10), carbenicillin (100), cefazolin (30), cefuroxime (30), cefoperazone (75), cefotaxime (30), chloramphenicol (30), ciprofloxacin (5), colistin (10), co-trimoxazole (25), doxycycline (10), erythromycin (15), gentamicin G (30), kanamycin (30), leucomycin (30), lomefloxacin (30), nitrofurantoin (300), norfloxacin (10), novobiocin (30), oleandomycin (15), penicillin $\mathrm{G}(10)$, polymyxin B (50 U), rifampicin (30), roxithromycin (30), spectinomycin (100), tetracycline (30), tobramycin (10) and vancomycin (30). The peptidoglycan contains lysine, glutamic acid and alanine, representing peptidoglycan type A4 $\alpha$. Polar lipids comprise phosphatidylglycerol, diphosphatidylglycerol and a compound that co-migrates with phosphatidylcholine; the predominant isoprenoid quinone is MK-7. The fatty acid composition is detailed in Table 2. Phylogenetically, a member of Bacillus RNA group 2.

The type strain is $\mathrm{PN}^{\mathrm{T}}\left(=\mathrm{LMG} 23935^{\mathrm{T}}=\mathrm{MTCC}^{\mathrm{N}} 127^{\mathrm{T}}\right.$ $=\mathrm{JCM} 15113^{\mathrm{T}}$ ), which was isolated from soil samples collected at an altitude of approximately $3500 \mathrm{~m}$ near the Pindari glacier of the Indian Himalayas.

\section{References}

Abd El-Rahman, H. A., Fritze, D., Spröer, C. \& Claus, D. (2002). Two novel psychrotolerant species, Bacillus psychrotolerans sp. nov. and Bacillus psychrodurans sp. nov., which contain ornithine in their cell walls. Int J Syst Evol Microbiol 52, 2127-2133.

Albert, R. A., Archambault, J., Rosselló-Mora, R., Tindall, B. J. \& Matheny, M. (2005). Bacillus acidicola sp. nov., a novel mesophilic, acidophilic species isolated from acidic Sphagnum peat bogs in Wisconsin. Int J Syst Evol Microbiol 55, 2125-2130.

Bae, S. S., Lee, J. H. \& Kim, S. J. (2005). Bacillus alveayuensis sp. nov., a thermophilic bacterium isolated from deep-sea sediments of the Ayu Trough. Int J Syst Evol Microbiol 55, 1211-1215.

Baker, G. C., Gaffar, S., Cowan, D. A. \& Suharto, A. R. (2001). Bacterial community analysis of Indonesian hot springs. FEMS Microbiol Lett 200, 103-109.

Brambilla, E., Hippe, H., Hagelstein, A., Tindall, B. J. \& Stackebrandt, E. (2001). $16 \mathrm{~S}$ rDNA diversity of cultured and uncultured prokaryotes of a mat sample from Lake Fryxell, McMurdo Dry Valleys, Antarctica. Extremophiles 5, 23-33.

Caccamo, D., Gugliandolo, C., Stackebrandt, E. \& Maugeri, T. L. (2000). Bacillus vulcani sp. nov., a novel thermophilic species isolated from a shallow marine hydrothermal vent. Int J Syst Evol Microbiol 50, 2009-2012.

Claus, D. \& Berkeley, R. C. W. (1986). Genus Bacillus Cohn 1872, $174^{\mathrm{AL}}$. In Bergey's Manual of Systematic Bacteriology, vol. 2, pp. 11051139. Edited by P. H. A. Sneath, N. S. Mair, M. E. Sharpe \& J. G. Holt. Baltimore: Williams \& Wilkins.

Cohn, F. (1872). Untersuchungen über Bakterien. Beitr Biol Pflanz Heft 2 1, 127-224 (in German).

Collins, M. D., Pirouz, T., Goodfellow, M. \& Minnikin, D. E. (1977). Distribution of menaquinones in actinomycetes and corynebacteria. J Gen Microbiol 100, 221-230.

Combet-Blanc, Y., Ollivier, B., Streicher, C., Patel, B. K., Dwivedi, P. P., Pot, B., Prensier, G. \& Garcia, J. L. (1995). Bacillus thermoamylovorans sp. nov., a moderately thermophilic and amylolytic bacterium. Int J Syst Bacteriol 45, 9-16.
Forsyth, G. \& Logan, N. A. (2000). Isolation of Bacillus thuringiensis from northern Victoria Land, Antarctica. Lett Appl Microbiol 30, 263-266.

Ghosh, A., Bhardwaj, M., Satyanarayana, T., Khurana, M., Mayilraj, S. \& Jain, R. K. (2007). Bacillus lehensis sp. nov., an alkalitolerant bacterium isolated from soil. Int J Syst Evol Microbiol 57, 238-242.

Gugliandolo, C., Maugeri, T. L., Caccamo, D. \& Stackebrandt, E. (2003). Bacillus aeolius sp. nov. a novel thermophilic, halophilic marine Bacillus species from Eolian Islands (Italy). Syst Appl Microbiol 26, 172-176.

Kimura, M. (1980). A simple method for estimating evolutionary rates of base substitutions through comparative studies of nucleotide sequences. J Mol Evol 16, 111-120.

Komagata, K. \& Suzuki, K. (1987). Lipid and cell-wall analysis in bacterial systematics. Methods Microbiol 19, 161-206.

Kumar, S., Tamura, K., Jakobsen, I.-B. \& Nei, M. (2001). MEGA2: molecular evolutionary genetics analysis software. Bioinformatics 17, $1244-1245$.

Lányí, B. (1987). Classical and rapid identification methods for medically important bacteria. Methods Microbiol 19, 1-67.

Larkin, J. M. \& Stokes, J. L. (1967). Taxonomy of psychrophilic strains of Bacillus. J Bacteriol 94, 889-895.

Lechner, S., Mayr, R., Francis, K. P., Prüß, B. M., Kaplan, T., WießnerGunkel, E., Stewart, G. S. \& Scherer, S. (1998). Bacillus weihenstephanensis sp. nov. is a new psychrotolerant species of the Bacillus cereus group. Int J Syst Bacteriol 48, 1373-1382.

Lee, J. C., Lim, J. M., Park, D. J., Jeon, C. O., Li, W. J. \& Kim, C. J. (2006). Bacillus seohaeanensis sp. nov., a halotolerant bacterium that contains L-lysine in its cell wall. Int J Syst Evol Microbiol 56, 1893-1898.

Lim, J. M., Jeon, C. O. \& Kim, C. J. (2006). Bacillus taeanensis sp. nov., a halophilic Gram-positive bacterium from a solar saltern in Korea. Int J Syst Evol Microbiol 56, 2903-2908.

Logan, N. A., Lebbe, L., Hoste, B., Goris, J., Forsyth, G., Heyndrickx, M., Murray, B. L., Syme, N., Wynn-Williams, D. D. \& De Vos, P. (2000). Aerobic endospore-forming bacteria from geothermal environments in northern Victoria Land, Antarctica, and Candlemas Island, South Sandwich archipelago, with the proposal of Bacillus fumarioli sp. nov. Int J Syst Evol Microbiol 50, 1741-1753.

Nelson, L. M. \& Parkinson, D. (1978). Growth characteristics of three bacterial isolates from an arctic soil. Can J Microbiol 24, 909-914.

Nogi, Y., Takami, H. \& Horikoshi, K. (2005). Characterization of alkaliphilic Bacillus strains used in industry: proposal of five novel species. Int J Syst Evol Microbiol 55, 2309-2315.

Pandey, K. K., Mayilraj, S. \& Chakrabarti, T. (2002). Pseudomonas indica sp. nov., a novel butane-utilizing species. Int J Syst Evol Microbiol 52, 1559-1567.

Priest, F. G., Goodfellow, M. \& Todd, C. (1988). A numerical classification of the genus Bacillus. J Gen Microbiol 134, 1847-1882.

Reddy, G. S. N., Aggarwal, R. K., Matsumoto, G. I. \& Shivaji, S. (2000). Arthrobacter flavus sp. nov., a psychrophilic bacterium isolated from a pond in McMurdo Dry Valley, Antarctica. Int J Syst Evol Microbiol 50, 1553-1561.

Reddy, G. S. N., Prakash, J. S. S., Matsumoto, G. I., Stackebrandt, E. \& Shivaji, S. (2002). Arthrobacter roseus sp. nov., a psychrophilic bacterium isolated from an Antarctic cyanobacterial mat sample. Int $J$ Syst Evol Microbiol 52, 1017-1021.

Reddy, G. S. N., Nagy, M. \& Garcia-Pichel, F. (2006). Belnapia moabensis gen. nov., sp. nov., an alphaproteobacterium from biological soil crusts in the Colorado Plateau, USA. Int J Syst Evol Microbiol 56, 51-58.

Rheims, H., Frühling, A., Schumann, P., Rohde, M. \& Stackebrandt, E. (1999). Bacillus silvestris sp. nov., a new member of the genus Bacillus that contains lysine in its cell wall. Int J Syst Bacteriol 49, 795-802. 
Rüger, H.-J., Fritze, D. \& Spröer, C. (2000). New psychrophilic and psychrotolerant Bacillus marinus strains from tropical and polar deepsea sediments and emended description of the species. Int J Syst Evol Microbiol 50, 1305-1313.

Shivaji, S., Chaturvedi, P., Suresh, K., Reddy, G. S. N., Dutt, C. B., Wainwright, M., Narlikar, J. V. \& Bhargava, P. M. (2006). Bacillus aerius sp. nov., Bacillus aerophilus sp. nov., Bacillus stratosphericus sp. nov. and Bacillus altitudinis sp. nov., isolated from cryogenic tubes used for collecting air samples from high altitudes. Int J Syst Evol Microbiol 56, 1465-1473.

Smibert, R. M. \& Krieg, N. R. (1994). Phenotypic characterization. In Methods for General and Molecular Bacteriology, pp. 607-654. Edited by P. Gerhardt, R. G. E. Murray, W. A. Wood \& N. R. Krieg. Washington, DC: American Society for Microbiology.

Spanka, R. \& Fritze, D. (1993). Bacillus cohnii sp. nov., a new, obligately alkaliphilic, oval-spore-forming Bacillus species with ornithine and aspartic acid instead of diaminopimelic acid in the cell wall. Int J Syst Bacteriol 43, 150-156.

Suresh, K., Reddy, G. S. N., Sengupta, S. \& Shivaji, S. (2004). Deinococcus indicus sp. nov., an arsenic-resistant bacterium from an aquifer in West Bengal, India. Int J Syst Evol Microbiol 54, 457-461.

Tamaoka, J. (1986). Analysis of bacterial menaquinone mixtures by reverse-phase high-performance liquid chromatography. Methods Enzymol 123, 251-256.

Tamaoka, J., Katayama-Fujimura, Y. \& Kuraishi, H. (1983). Analysis of bacterial menaquinone mixtures by high performance liquid chromatography. J Appl Bacteriol 54, 31-36.
Thompson, J. D., Higgins, D. G. \& Gibson, T. J. (1994). Clustal W: improving the sensitivity of progressive multiple sequence alignment through sequence weighting, position-specific gap penalties and weight matrix choice. Nucleic Acids Res 22, 4673-4680.

Vargas, V. A., Delgado, O. D., Hatti-Kaul, R. \& Mattiasson, B. (2005). Bacillus bogoriensis sp. nov., a novel alkaliphilic, halotolerant bacterium isolated from a Kenyan soda lake. Int J Syst Evol Microbiol 55, 899-902.

Venkateswaran, K., Kempf, M., Chen, F., Satomi, M., Nicholson, W. \& Kern, R. (2003). Bacillus nealsonii sp. nov., isolated from a spacecraftassembly facility, whose spores are gamma-radiation resistant. Int $J$ Syst Evol Microbiol 53, 165-172.

Wayne, L. G., Brenner, D. J., Colwell, R. R., Grimont, P. A. D., Kandler, O., Krichevsky, M. I., Moore, L. H., Moore, W. E. C., Murray, R. G. E. \& other authors (1987). International Committee on Systematic Bacteriology. Report of the ad hoc committee on reconciliation of approaches to bacterial systematics. Int J Syst Bacteriol 37, 463-464.

Yoon, J. H., Lee, K. C., Weiss, N., Kho, Y. H., Kang, K. H. \& Park, Y. H. (2001). Sporosarcina aquimarina sp. nov., a bacterium isolated from seawater in Korea, and transfer of Bacillus globisporus (Larkin and Stokes 1967), Bacillus psychrophilus (Nakamura 1984) and Bacillus pasteurii (Chester 1898) to the genus Sporosarcina as Sporosarcina globispora comb. nov., Sporosarcina psychrophila comb. nov. and Sporosarcina pasteurii comb. nov., and emended description of the genus Sporosarcina. Int J Syst Evol Microbiol 51, 1079-1086.

Yumoto, I., Yamazaki, K., Sawabe, T., Nakano, K., Kawasaki, K., Ezura, Y. \& Shinano, H. (1998). Bacillus horti sp. nov., a new Gramnegative alkaliphilic bacillus. Int J Syst Bacteriol 48, 565-571. 